\title{
Restriction-deficient Mutants of Staphylococcus aureus
}

\author{
By ELLEN E. STOBBERINGH AND K. C. WINKLER \\ Laboratory of Microbiology, State University Utrecht, Catharijnesingel 59, \\ Utrecht, The Netherlands
}

(Received 13 July 1976; revised 27 September 1976)

\begin{abstract}
SUMMARY
A series of restriction-deficient mutants was isolated from non-lysogenic strains of Staphylococcus aureus belonging to phage groups I and II. Some mutants were sensitive to all phages tested. With one possible exception, all the mutants were unaffected in their modification systems. The breakdown of DNA of phages, restricted in the parental strains, was reduced in both the mutants that were tested. The restriction in propagating strain $3 \mathrm{~A}$ could be transduced to its restrictiondeficient mutant. The transduction efficiency increased after ultraviolet irradiation of the transducing phage suggesting that the gene for restriction is present on the bacterial chromosome.
\end{abstract}

\section{INTRODUCTION}

The phage patterns of Staphylococcus aureus fall into groups I, II, III, and IV. The strains in each group are mainly sensitive to phages of the same group. As nearly all phages are adsorbed by all strains, the insensitivity of a strain to a phage is either due to lysogenic immunity or to restriction and modification. Different patterns within a group are often due to lysogenic immunity (Rountree, 1959; Blair \& Carr, 1961 ; Winkler \& Grootsen, 196I ; Asheshov \& Winkler, 1966). Differences between groups are thought to be due to restriction and modification (Ralston \& Baer, 1964a, b, $c$; van Boven et al., 1974; Stobberingh, 1975). Indicator strains heated for a short time at $56{ }^{\circ} \mathrm{C}$ can often be used to differentiate between restriction and lysogenic immunity, since heating reduces restriction but does not affect immunity (Asheshov \& Jevons, 1963; Ma \& Mandle, 1961).

All work on restriction and modification in $S$. aureus is based on plating efficiencies, on host ranges of modified phages and on the reduction of restriction in heated bacteria. The theory is borrowed from the well-described restriction systems in Escherichia coli (Arber \& Dussoix, 1962; Arber \& Linn, 1969; Boyer, 1971; Arber, 1974). This paper describes experiments designed to produce other evidence for restriction systems in $S$. aureus.

\section{METHODS}

Media. Nutrient broth and nutrient broth agar (Difco) with $\mathrm{CaCl}_{2}\left(876 \mathrm{mg}^{-1}\right)$ were used throughout.

Phage-typing was done according to Blair \& Williams (196I) but the plates were incubated at $37^{\circ} \mathrm{C}$ instead of $30^{\circ} \mathrm{C}$ to reduce restriction. Indicator plates with heated bacteria were prepared by heating $2 \mathrm{ml}$ of an overnight culture in a water bath for $2 \mathrm{~min}$ at $56^{\circ} \mathrm{C}$ (survival $70 \%$ ) before flooding.

Coagulase (tube test) and fermentation tests were performed as described by BairdParker (1963). DNAase was tested on DNase test agar (BBL). Antibiotic sensitivity was determined on sensitivity agar (Difco) with Multodisks (Oxoid). 
Strains. The propagating strains (PS) of the International Phage Typing System and the non-lysogenic strains 879 (group II; Winkler \& Grootsen, I96I) and 57 (Winkler et al., 1965) were used. The cured strains 8oc, derived from PS 80 (NCTC9789) (Asheshov \& Winkler, 1966), and CV4 (Van der Vijver, van Es-Boon \& Michel, 1975) were obtained from the appropriate authors. PS 29 and PS 7I (respectively NCTC833I and NCTC93I5) were cured to give strains $29 \mathrm{C}$ and $71 \mathrm{C}$.

Curing. Two $\mathrm{ml}$ of an $\mathrm{I} 8 \mathrm{~h}$ broth culture was incubated for $10 \mathrm{~min}$ at $37^{\circ} \mathrm{C}$ with $\mathrm{I} \mathrm{ml}$ of a I : 100 dilution of rabbit antiserum specific against each lysogenic phage $(K>100)$. Mitomycin C (Kyowa Hakko Kogyo Co., Tokyo, Japan) was then added at $0.5 \mu \mathrm{g} \mathrm{ml}^{-1}$. Samples were taken after various incubation times and spread on agar plates and the colonies were tested for phage sensitivity by cross-streaking. After mitomycin induction, cured strains yielded no phage using strain 80C R3 (see below) as indicator.

Mutagenic treatment. Ethyl methanesulphonate (EMS; Koch-Light) was dissolved in a solution containing $\left(\mathrm{g} \mathrm{l}^{-1}\right)$ : Mohr's salt $6 \mathrm{H}_{2} \mathrm{O}, 0.028 ; \mathrm{MgSO}_{4} \cdot 7 \mathrm{H}_{2} \mathrm{O}, 0.2 ; \mathrm{NH}_{4} \mathrm{Cl}, 8$; $\mathrm{KH}_{2} \mathrm{PO}_{4}$, 18 . This stock solution ( $\mathrm{pH} \mathrm{6.8)}$ was sterilized by filtration and diluted $\mathrm{I}: 8$ with distilled water before use.

An overnight broth culture ( $\mathrm{I} \mathrm{ml)} \mathrm{was} \mathrm{mixed} \mathrm{with} \mathrm{I} \mathrm{ml} \mathrm{of} \mathrm{a} 0.5 \%(\mathrm{v} / \mathrm{v})$ or $0.25 \%(\mathrm{v} / \mathrm{v})$ solution of EMS and incubated for $30 \mathrm{~min}$ at $37^{\circ} \mathrm{C}$. EMS was neutralized with $8 \mathrm{ml} 5 \%$ (w/v) $\mathrm{Na}_{2} \mathrm{~S}_{2} \mathrm{O}_{3}$; the bacteria were collected by centrifuging, washed once with broth and resuspended in $5 \mathrm{ml}$ broth. The surviving population (0.0I to $0.1 \%$ ) was incubated for $5 \mathrm{~h}$ at $37^{\circ} \mathrm{C}$ for expression.

$N$-methyl- $N^{\prime}$-nitro- $N$-nitrosoguanidine (NTG; Koch-Light; I mg) was dissolved in $25 \mathrm{ml}$ Tris/maleic acid buffer (6. I $\mathrm{g}$ Tris and $5.8 \mathrm{~g}$ maleic acid $\mathrm{l}^{-1}, \mathrm{pH} \mathrm{6 \cdot 0)}$. An overnight culture $(5 \mathrm{ml})$ was centrifuged and the pellet was resuspended in $2.5 \mathrm{ml} \mathrm{NTG}$ solution. After incubation for $30 \mathrm{~min}$ at $37^{\circ} \mathrm{C}$, NTG was removed by washing with cold broth. The bacteria were resuspended in $5 \mathrm{ml}$ fresh broth and incubated for $18 \mathrm{~h}$ at $37^{\circ} \mathrm{C}$ for expression. NTG was only used for isolating mutants of strain 879 .

The presence of mutants was tested by adsorbing a restrictive phage to a sample of the population and plating this on to the parental strain. The presence of a larger number of plaques than were found in the control sample indicated the presence of $r^{-} \mathrm{m}^{+}$mutants able to propagate and modify the phage.

Isolation of mutants. Populations containing 40 to 63 mutants per $10^{6}$ survivors were plated on nutrient agar. After incubation the colonies were tested for sensitivity to the restrictive phage either by replica-plating on a plate flooded with this phage or by streaking individual colonies across a streak of the restrictive phage. Colonies showing lysis were selected as possible $\mathrm{r}^{-} \mathrm{m}^{-}$or $\mathrm{r}^{-} \mathrm{m}^{+}$mutants. To isolate $\mathbf{r}^{-} \mathrm{m}^{-}$mutants separate colonies were streaked across adjacent streaks of the restrictive phage and the parental strain. Possible mutants were phage-typed and if they differed from the parental strain all relevant phages were titrated quantitatively on fresh and heated cells.

Phage-labelling. Five $\mathrm{ml}$ broth containing 2-deoxyadenosine $\left(50 \mu \mathrm{g} \mathrm{ml}^{-1}\right)$ and $\left[\right.$ methyl $\left.{ }^{-3} \mathrm{H}\right]-$ thymidine $\left(50 \mathrm{mCi} \mathrm{ml}^{-1} ; 80 \mathrm{mCi} \mathrm{mg}^{-1}\right.$ ) was inoculated with about $10^{8}$ bacteria from an overnight culture and shaken for $30 \mathrm{~min}$ at $37^{\circ} \mathrm{C}$. About $10^{7}$ (plaque-forming units) p.f.u. of phage was then added together with $\mathrm{CaCl}_{2}\left(876 \mathrm{mg} \mathrm{1}^{-1}\right.$ ). After lysis (about $4 \mathrm{~h}$ at $37^{\circ} \mathrm{C}$ ) $0.5 \mathrm{ml}$ DNAase (BDH; I mg ml-1), $0.1 \mathrm{ml} 0.0 \mathrm{I} \mathrm{M}-\mathrm{MgCl}_{2}$ and $0.1 \mathrm{ml} 0.0 \mathrm{r} \mathrm{M}$-Tris buffer were added and the mixture was kept at $37^{\circ} \mathrm{C}$. After centrifuging at $2000 \mathrm{~g}$ to remove debris, the phage was concentrated by centrifuging at $90000 \mathrm{~g}$ for $2 \mathrm{~h}$. The sediment was taken up in $6 \mathrm{ml}$ broth and kept at $4{ }^{\circ} \mathrm{C}$. The activity was about I d.p.m. per $10^{4}$ p.f.u.

Degradation of labelled phage DNA. Labelled phage ( $\mathrm{ml} ; 3 \times 10^{8}$ p.f.u.) was mixed with 
$3 \times 10^{8}$ bacteria (at the end of the exponential growth phase) in $\mathrm{I} \mathrm{ml}$ nutrient broth with $0.1 \mathrm{ml} \mathrm{CaCl}{ }_{2}\left(876 \mathrm{mg} \mathrm{l}^{-1}\right)$ and methionine ( $\left.\mathrm{I} \mathrm{mg} \mathrm{ml}^{-1}\right)$. After adsorption for $\mathrm{Io}$ min at $4{ }^{\circ} \mathrm{C}$ the suspension was centrifuged at room temperature, washed with cold broth, resuspended in $2 \mathrm{ml}$ broth and incubated in a water bath at $30^{\circ} \mathrm{C}$ for $30 \mathrm{~min}$. Samples $(0.2 \mathrm{ml})$ were removed at intervals and the activity of the trichloroacetic acid (TCA)-soluble fraction was determined, as a measure of DNA breakdown (Simmon \& Lederberg, 1972; Verhoef, van Boven \& Holtrigter, 1972). Data are given as a percentage of the total activity (d.p.m.) of a sample taken at zero time (without TCA). Activity was determined by adding each sample to $10 \mathrm{ml}$ of counting fluid [toluene $(750 \mathrm{ml})$ plus Triton X-100 $(250 \mathrm{ml})$ containing $500 \mathrm{mg} \mathrm{2,5}$-diphenyloxazole and $50 \mathrm{mg} \mathrm{I,4-bis-(4-methyl-5-phenyloxazol-2-yl)benzene]} \mathrm{and}$ counting in a Nuclear Chicago mark II scintillation counter.

Transduction was performed as described by Asheshov (1966). Phage (I0 ${ }^{10}$ p.f.u.) was added to $9 \mathrm{ml}$ of an overnight culture $\left[10^{9}\right.$ colony-forming units $\mathrm{ml}^{-1}$ ] in broth with $\mathrm{CaCl}_{2}$ $\left(200 \mathrm{mg}^{-1}\right.$ ). The mixture was incubated for $15 \mathrm{~min}$ at $37^{\circ} \mathrm{C}$ and centrifuged at $2000 \mathrm{~g}$. The sediment was resuspended in $20 \mathrm{ml}$ nutrient broth containing $0.01 \mathrm{M}$-sodium citrate and incubated for $3 \mathrm{~h}$ at $37^{\circ} \mathrm{C}$. After centrifugation and washing with broth the sediment was incubated with 3 to $5 \mathrm{ml}$ of restrictive phage (multiplicity of infection about 10 ) for 30 min at $37^{\circ} \mathrm{C}$ and plated. A control culture without transducing phage was treated in the same way. All colonies were tested for sensitivity against the selecting phage and possible transductants were phage-typed.

\section{RESULTS}

\section{Cured and non-lysogenic strains}

For genetic studies on restriction systems, parental strains without lysogenic immunity are preferable. The phage patterns of the non-lysogenic strain 879 and the cured strains $80 \mathrm{C}, \mathrm{CV} 4$ and $29 \mathrm{C}$ are given in Fig. I together with the patterns of the strains from which they are derived. The phage pattern of the non-lysogenic PS 3A (NCTC8319) is shown in Fig. 2.

The cured strains of group I (29C, $\mathrm{CV}_{4}$ and $\left.80 \mathrm{C}\right)$ are sensitive to all group I phages but are nsensitive to many group II and III phages.

\section{Restriction-deficient mutants}

A number of the strains in Fig. I were treated with mutagens and the resulting populations were tested for colonies sensitive to a restricted phage (selecting phage). Most such possible mutants proved to be unstable and reverted to the parental pattern on subcultivation. About 1500 colonies had to be tested in each experiment to isolate a mutant that was stable on subcultivation. None of the isolated mutants (Table I) differed from the parent strain with regard to their general properties, such as fermentation, DNAase production, coagulase production and antibiotic resistance.

The phage patterns established by quantitative phage titrations of some mutants are shown in Fig. 2. PS 3A is a non-lysogenic group II strain, restrictive for all group I and III phages. The mutant 3A RI had become sensitive to all phages tested. It appeared to be the result of a one-step mutation, and this was confirmed by a back mutation rate of $4 \times 10^{-8}$ from 3A RI to 3A. This suggests that one $\mathrm{rm}$ system $\left(\mathrm{rm}_{\mathrm{II}}\right)$ is responsible for the insensitivity of PS 3 A to phages of groups I and III.

Strain 879 , also a non-lysogenic group II strain, is insensitive to many group I and III phages. It also shows a weak $\left(\mathrm{IO}^{-2}\right)$ restriction for phage $3 \mathrm{~A}$ as detected by heating. Several mutants were isolated from this strain. Mutant 879 R I (selected with phage $3 \mathrm{~A}$ ) is a one-step 


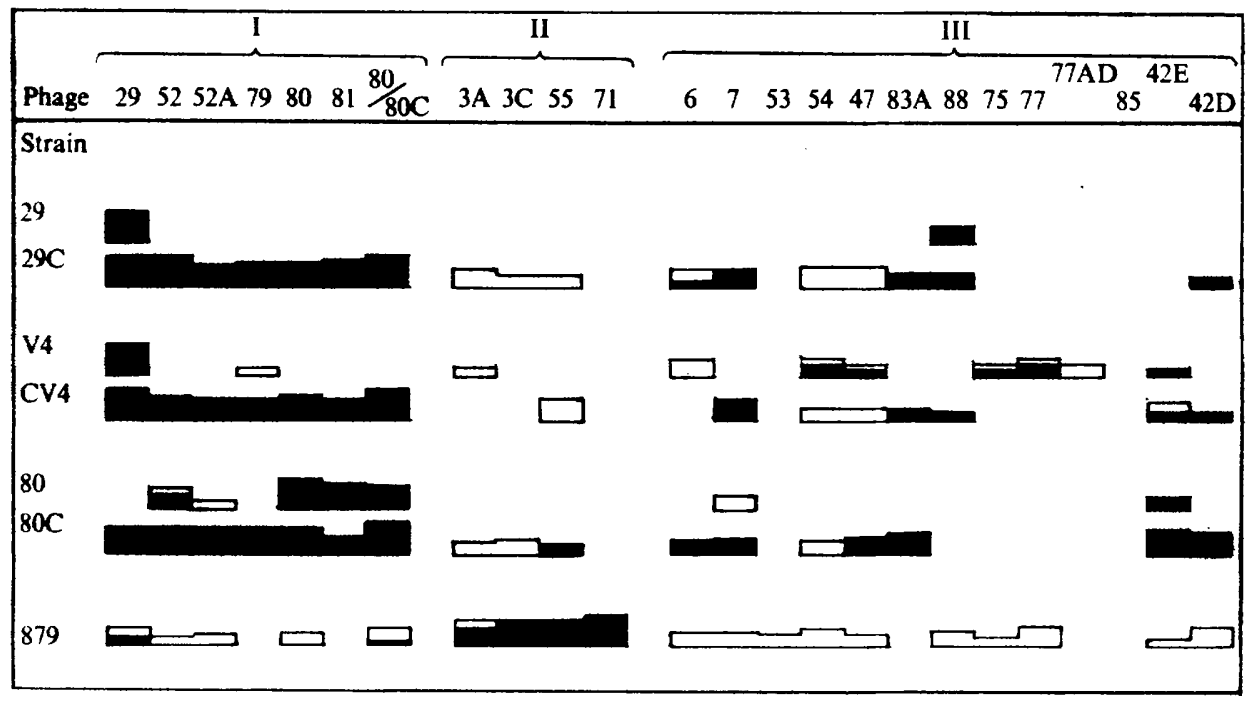

Fig. I. Quantitative phage patterns of non-lysogenic and cured strains and their parents. Black columns represent the $\log _{10}$ of the phage titre on each strain $\left(\log _{10}\right.$ of the phage titre on the PS $=8$ ). White columns represent titres on heated bacteria of each strain.

Table I. Isolated mutants

\begin{tabular}{|c|c|c|c|c|}
\hline Strain & Selecting phage & $\begin{array}{l}\text { Independent } \\
\text { isolations }\end{array}$ & Mutant & Phenotype (hypothetical) \\
\hline $3 \mathrm{~A}$ & $80 / 80 \mathrm{C}$ & 4 & 3A RI & $r_{3 \Lambda}+m_{3 \Lambda}+r_{I I}-m_{I I}^{+}$ \\
\hline 879 & $3 \mathbf{A}$ & 9 & $879 \mathrm{RI}$ & $\mathrm{r}_{879}-\mathrm{m}_{\mathrm{879}}+\mathrm{r}_{1 \mathrm{II}}{ }^{+} \mathrm{m}_{\mathrm{II}}{ }^{+}$ \\
\hline 879 & $80 / 80 \mathrm{C}$ & 4 & 879 R2 & $\mathrm{r}_{879}+\mathrm{m}_{879}+\mathrm{r}_{\mathrm{II}}-\mathrm{m}_{\mathrm{II}}^{+}$ \\
\hline 879 R2 & 6 & $\mathbf{I}$ & 879 R3 & $r_{879}-m_{879}+r_{\Pi 1}-m_{I I}{ }^{+}$ \\
\hline $80 \mathrm{C}$ & 54 & 3 & $80 \mathrm{C} \mathrm{RI}$ & $r_{80 \Lambda^{ \pm}} m_{80 \mathrm{~A}}+r_{80 \mathrm{~B}}+\mathrm{m}_{80 \mathrm{~B}}{ }^{+}$ \\
\hline $80 \mathrm{C} \mathrm{R} 1$ & $3 \mathbf{A}$ & $\mathbf{I}$ & $80 \mathrm{C}$ R2 & $r_{80 A}-m_{80 A}-r_{80 B}+m_{80 B}+$ \\
\hline $80 \mathrm{C}$ R2 & 71 & 1 & $80 \mathrm{C}$ R3 & $r_{80 A}-m_{80 A^{-}} r_{80 B}-m_{80 B}{ }^{+}$ \\
\hline cv4 & 54 & 4 & CV4 RI & \\
\hline
\end{tabular}

mutant, lacking the restriction for phage $3 \mathrm{~A}$ and with reduced restriction for some group I phages. Mutant 879 R2, selected with phage $80 / 80 \mathrm{C}$, is a separate one-step mutant with reduced restriction for many phages in groups I and III, but still restrictive for phage 3A. Mutant 879 R3, isolated from strain 879 R2 with phage 6 as selecting phage, appears to be a double mutant sensitive to most group I and III phages with the exception of phages 75 , $77,77 \mathrm{~A}$ and 85 .

After mutagenic treatment of strain $80 \mathrm{oc}$, and with phage 54 as the selecting phage, the mutant $80 \mathrm{C}$ RI was obtained. This is more sensitive to group III phages, but the sensitivity still increases after heating. Subsequent treatment of strain $80 \mathrm{C} \mathrm{RI}$ and selection with phage 3A resulted in mutant 80C R2, which had lost the restriction for all group III phages $\left(=\mathrm{rm}_{80 A}\right)$ as shown by the similar sensitivity for these phages before and after heating. The restriction for group II phages $\left(=\mathrm{rm}_{80 \mathrm{~B}}\right)$ still existed. This $\mathrm{rm}_{80 \mathrm{~B}}$ system was eliminated in mutant $80 \mathrm{C} \mathrm{R3}$, obtained after mutagenic treatment of strain 80C R2 and selection with phage 7I. This mutant is sensitive to all group I, II and III phages.

Four independent mutants (CV4 RI) with the same pattern were obtained from strain CV4. 


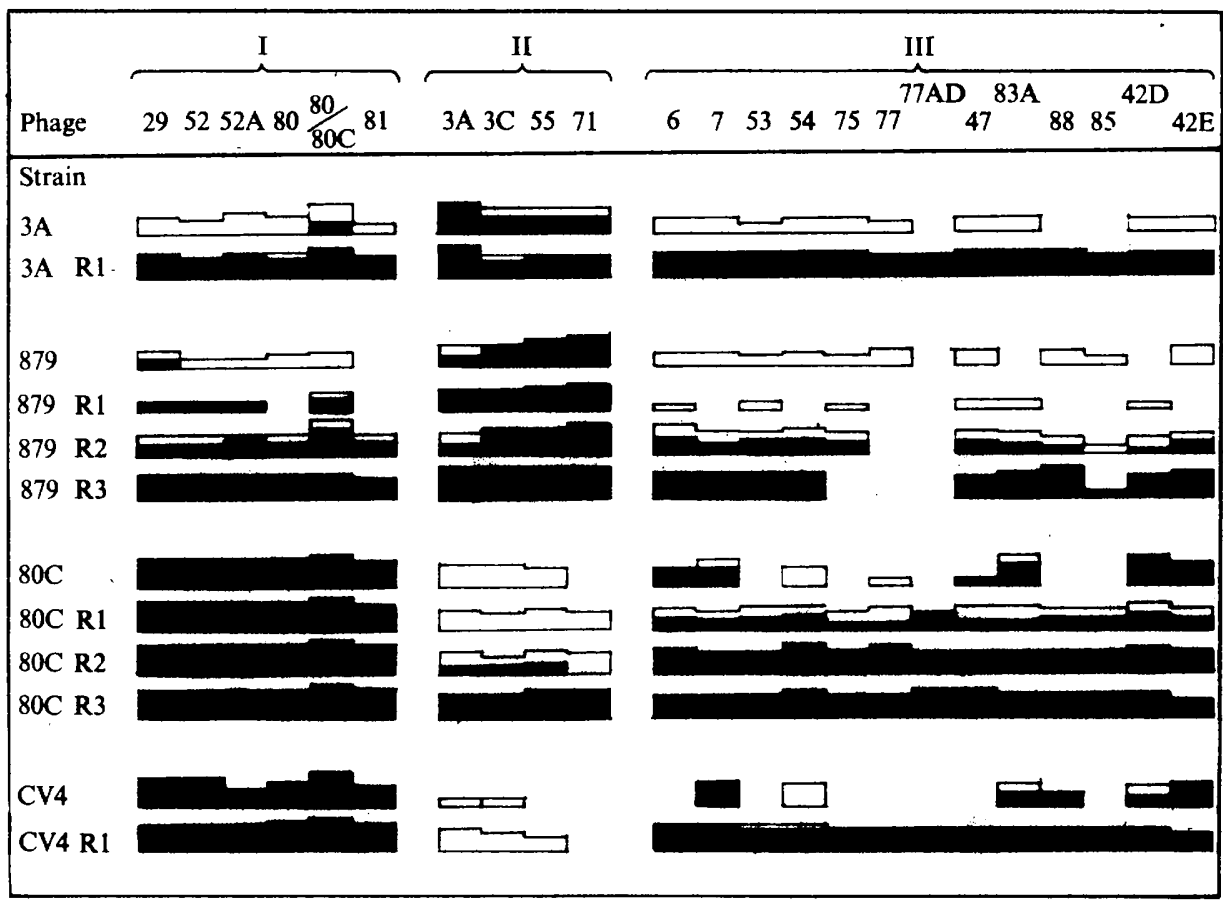

Fig. 2. Quantitative phage patterns of $\mathbf{r}^{-}$mutants. For details see legend to Fig. $\mathbf{I}$.

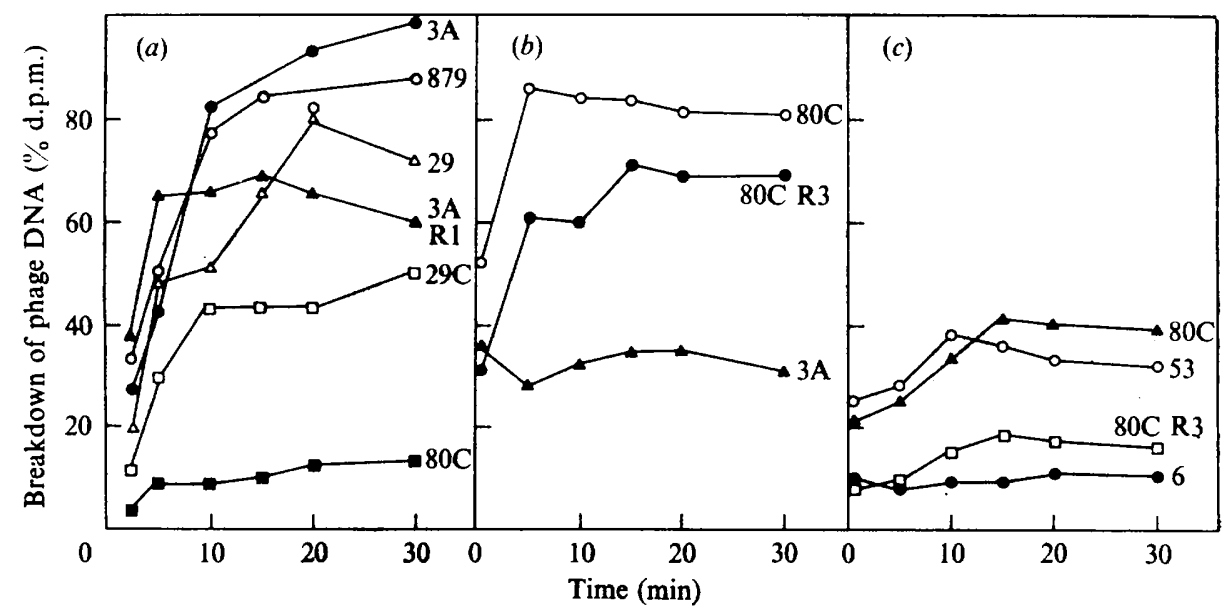

Fig. 3. Breakdown of $\left[{ }^{2} \mathrm{H}\right]$ thymidine-labelled phage DNA in various strains. $(a)$ Phage $80 / 80 \mathrm{C}$ in the restrictive strains $879(O)$ and $3 A(O)$, the restriction-deficient mutant $3 A$ RI $(\Delta)$, in the group I strain $29(\triangle)$ and its cured derivative $29 \mathrm{C}(\square)$, and in the non-restrictive strain $80 \mathrm{C}(\mathrm{D})$. (b) Phage $3 A$ in the restrictive strain $80 C(O)$, its restriction-deficient mutant $80 C$ R3 (O), and PS $3 A(\Delta)$. (c) Phage 6 in the restrictive strains PS $53(O)$ and $80 \mathrm{C}(\Delta)$, in the restriction-deficient mutant $80 \mathrm{C}$ R3 ( $\square$ ), and in PS 6 (O). Results show the radioactivity (d.p.m.) in the TCA-soluble fraction as a percentage of the total activity in a reference sample (no TCA extraction) at zero time. The degradation in restrictive samples at time zero is probably a result of centrifugation at room temperature. 


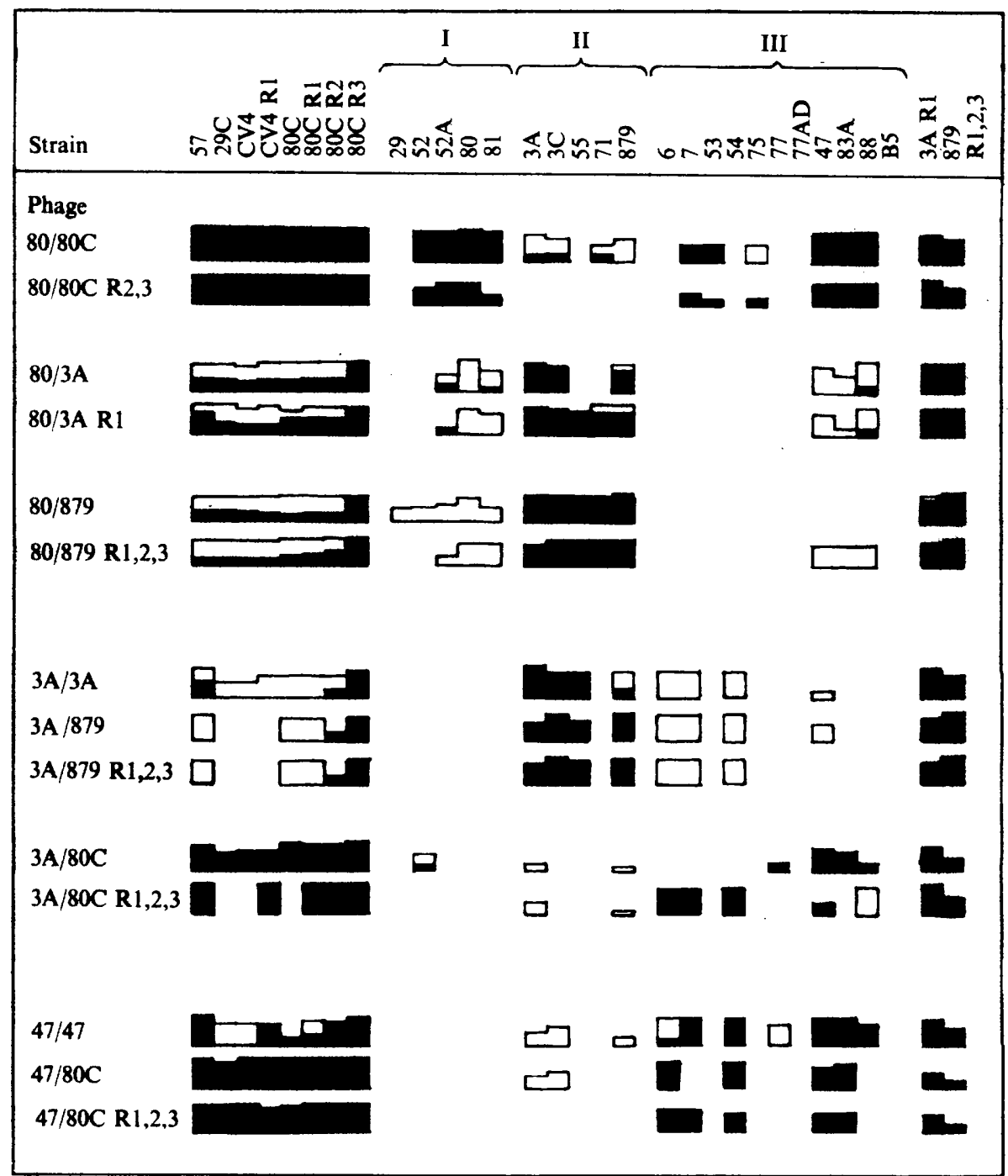

Fig. 4. Modification by mutants. Quantitative phage patterns of various phages propagated on parental strains and restriction-deficient mutants. For details, see legend to Fig. I.

The restriction for group III phages was reduced in these mutants. The restriction for group II phages still existed. Attempts to eliminate this rm system were not successful.

\section{Degradation of labelled phage DNA}

Figure $3(a)$ shows the breakdown of phage 80 propagated on strain $80 \mathrm{C}$ in the restrictive strains 879 and $3 \mathrm{~A}$. Breakdown in the restriction-deficient mutant $3 \mathrm{~A}$ RI and in the group I strain $29 \mathrm{C}$ was much less. In strain $80 \mathrm{C}$ less than $15 \%$ of the DNA appeared in the soluble fraction. Figure $3(b)$ shows that the DNA of labelled phage $3 \mathrm{~A}$ was relatively stable in PS $3 \mathrm{~A}$, but quickly broken down in strain $80 \mathrm{C}$ and to a lesser extent in the mutant $80 \mathrm{C}$ R3. Breakdown of the DNA of phage $3 \mathrm{~A}$ was also observed in the restrictive strains 57,879 and PS 6. Phage 7I was broken down $(30 \%)$ in the restrictive strain $3 \mathrm{~A}$ but not $(6 \%)$ in the 
permissive strain 879 . Figure $3(c)$ shows the breakdown of phage 6 in the restrictive strains $80 \mathrm{C}$ and 53 and the reduced breakdown in mutant $80 \mathrm{C}$ R3.

Analogous experiments with restrictive strains after heating always confirmed that DNA breakdown was reduced in heated strains.

It should be noted that a restriction measured by phage titre (efficiency of plating) as $10^{-3}$ or $10^{-6}$ means that $I$ in 1000 or $I$ in $10^{6}$ phage particles escape. In both cases over $99 \%$ of the phage DNA is broken down. A quantitative relationship between restriction and DNA breakdown cannot therefore be expected. Furthermore the TCA-soluble DNA represents the effect of exonucleases on the large DNA pieces presumably produced by the restriction endonuclease and is not a direct measure of restriction.

\section{Modification by mutants}

In $E$. coli about $50 \%$ of the isolated $\mathrm{r}^{-}$mutants are also $\mathrm{m}^{-}$(Glover, I970; Wood, 1966). The modification behaviour of our mutants was studied by comparing the host range of various phages after propagation on parent and mutant strains (Fig. 4). The reversal patterns after re-propagation on the original PS have not been included in Fig. 4. The sensitivity of the non-lysogenic strains, shown on the left, is the best parameter for modification of a phage. Phage 80 propagated on strains $80 \mathrm{C} \mathrm{R2}$ or $80 \mathrm{C} \mathrm{R} 3$ retains approximately its original host range, suggesting that the mutants are $\mathrm{m}^{+}$. Phage 80 causes plaques on heated cells of PS 3A (Fig. 2) and can then be propagated on PS 3A. Figure 4 shows that phage 80/3A is modified to a phage with a group II pattern. Propagation on strain $3 \mathrm{~A}$ RI produces a comparable modification. Strain 879 and its mutants also modify phage 80 to phages with a group II pattern.

Phage 3A propagated on strain 879 or its mutants receives the 879 modification, with restriction in PS $3 \mathrm{~A}$.

The modification behaviour of strain $80 \mathrm{C} \mathrm{R2}$ (and 8OC R3) was not the same for all phages (Stobberingh, 1975). Phage 80/80C keeps its group I pattern after propagation on these mutants (Fig. 4, line 2). The same was true for phage 29 (group I). Phage 47 (group III) also had a group I pattern and had lost several reactions in group III after propagation on strains 8OC, $80 \mathrm{C} \mathrm{RI}$, 8OC R2 or 8OC R3 (Fig. 4, lines I 2 to I4). In contrast, phage 3A (Fig. 4, lines Io and $\mathrm{II}$ ) though modified by strain $80 \mathrm{C}$ to a group I pattern, did not obtain this modification in the mutants, although it lost its group II modification. The same was true for phages ${ }_{3} \mathrm{C}$ and $7 \mathrm{I}$. This suggests that the modification system $\mathrm{rm}_{80 \mathrm{~s}}$ is altered. With this exception, all the isolated mutants were $r^{-} m^{+}$. All attempts to isolate $\mathrm{m}^{-}$mutants either from $\mathrm{r}^{-}$ mutants or from parental strains were unsuccessful.

\section{Transduction of $\mathrm{rm}_{3 A}$ to mutant 3A RI}

In other genera, genes coding for rm systems have been found on the chromosome, on plasmids and on lysogenic phages. Asheshov \& Rippon (1959) showed the presence of a restriction system on the lysogenic phage F in PS 80 . It was important to know the localization of an rm system affecting a whole phage group. Thus a transduction experiment was performed with phage 80/3A as a transducing phage and the mutant strain $3 \mathrm{~A} \mathrm{RI}$ as recipient. After expression, the population was infected with phage 6 as the selecting phage and the infected bacteria were plated. As all parental bacteria would be killed by the selecting phage, the survivors would either be transductants or bacteria which had escaped infection. All growing colonies were tested for sensitivity to the selecting phage and possible transductants were phage-typed. Control plates from experiments without transducing phage were mainly negative, thus excluding back mutations. 


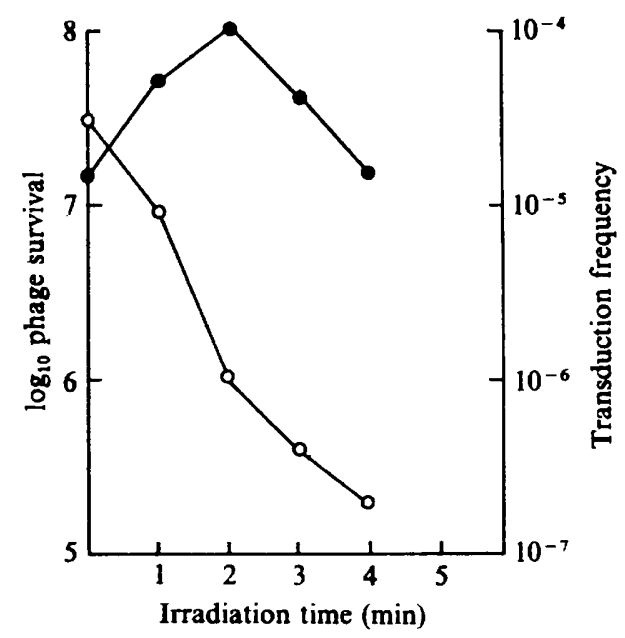

Fig. 5. Transduction of restriction from PS $3 A$ to restriction-deficient mutant 3A RI, with phage $80 / 3 \mathrm{~A}$ as transducing phage and phage 6 as selecting phage. The transducing phage was irradiated with ultraviolet light on a mechanical shaker. $O$, Phage survival; $O$, transduction frequency.

Experiments with ultraviolet-irradiated transducing phage gave the results shown in Fig. 5. The transduction frequency of $10^{-5}$ increased to $10^{-4}$ after $2 \mathrm{~min}$ of ultraviolet irradiation. This character is generally present in transduction of chromosomal markers (Arber, 1960).

\section{DISCUSSION}

The groups of strains of $S$. aureus with related phage patterns are thought to be restriction groups carrying different rm systems. This conception is supported by the phage patterns of the cured strains (Fig. I) and particularly by the patterns of the isolated mutants (Fig. 2). The mutants generally gained sensitivity for a whole group of phages in one step. It is also interesting that so many independent mutants had the same phage pattern (Table $\mathrm{I}$ ).

Mutant 3A RI appears to be a one-step mutant, both from its origin and its back mutation rate. The reduced breakdown of phage DNA in this mutant (Fig. $3 a$ ) shows that it is deficient in restriction. The frequency of transduction of restriction from PS $3 \mathrm{~A}$ to strain 3A RI is rather high but the increase of transduction frequency after ultraviolet irradiation of the transducing phage is consistent with a chromosomal localization of the gene coding for the presumed restriction enzyme. Sussenbach, Monfoort \& Stobberingh (1976) isolated and characterized a restriction enzyme from strain 3A, which broke the DNA of phage 6 in many pieces, but did not affect the DNA of phage 3A. The enzyme did not require $S$-adenylmethionine or ATP. No such enzyme activity was detectable in extracts of strain 3A RI.

For the other mutants the picture is less complete. The different mutants of strains 879 and $80 \mathrm{C}$ certainly carry different mutations and $80 \mathrm{C} \mathrm{R3}$ and 879 R3 are presumably double mutants. All mutants tested were deficient in the breakdown of phage DNA (Fig. 3) but the experiments with labelled phage cannot differentiate between strong and weak restriction. The different mutations in mutant $80 C$ R3 might be mutations in different enzymes (as suggested in Table I, last column) or different mutation of the same enzyme. In the latter case, the mutation should affect the recognition site or the affinity of the enzyme as the activity against phages of other groups is not affected. 
With one possible exception, no $\mathrm{r}^{-} \mathrm{m}^{-}$mutants were obtained by us or by Dr E. H. Asheshov (personal communication). This lack of $\mathrm{rm}^{-}$mutants makes it unlikely that the rm systems in $S$. aureus are governed by a three-gene system as are those of type I in $E$. coli. Together with the properties of the enzyme isolated from PS $3 \mathrm{~A}$, it seems more likely that the rm systems are of type II.

\section{REFERENCES}

ARBER, W. (1960). Transduction of chromosomal genes and episomes in Escherichia coli. Virology I1, 273-288. Arber, W. (1974). DNA modification and restriction. Progress in Nucleic Acid Research and Molecular Biology 14, I-37.

ARBer, W. \& Dussolx, D. (1962). Host specificity of DNA produced by Escherichia coli I. Host control modification of bacteriophage $\lambda$. Journal of Molecular Biology 5, 18-36.

ARBER, W. \& LINN, S. (1969). DNA modification and restriction. Annual Review of Biochemistry 38, 467-500.

AsHeshov, E. H. (1966). Chromosomal location of the genes controlling penicillinase production in a strain of Staphylococcus aureus. Nature, London 2ro, 804-806.

Asheshov, E. H. \& Jevons, M. P. (1963). The effect of heat on the ability of a host strain to support the growth of a staphylococcus phage. Journal of General Microbiology 31, 97-107.

Asheshov, E. H. \& RIPPON, J. E. (1959). Changes in typing pattern of phage-type 80 staphylococci. Journal of General Microbiology 20, 634-643.

Asheshov, E. H. \& WINKLER, K. C. (1966). Staphylococcus aureus strains in the ' 52,52 A, 80, $8 \mathrm{I}$ ' complex. Nature, London 290, 638-639.

Baird-Parker, A. C. (1963). A classification of micrococci and staphylococci based on physiological and biochemical tests. Journal of General Microbiology 30, 409-427.

BLAIR, J. E. \& CARR, M. (1961). Lysogeny in staphylococci. Journal of Bacteriology 82, 984-993.

Blair, J. E. \& Williams, R. E. O. (1961). Phage-typing of staphylococci. Bulletin of the World Health Organization 24, 771-784.

van Boven, C. P. A., Stobberingh, E. E., Verhoef, J. \& Winkler, K. C. (1974). Restriction and modification of phages in staphylococcal phage typing. Annals of the New York Academy of Sciences 236, 376-388.

BOYER, H. W. (1971). DNA restriction and modification mechanisms in bacteria. Annual Review of Microbiology 25, $153-176$.

GLOVER, S. W. (1970). Functional analysis of host-specificity mutants in Escherichia coli. Genetical Research $15,237^{-250}$

MA, P. \& MANDLE, R. J. (1961). Phage typing 'nontypable' strains of Staphylococcus aureus. Bacteriological Proceedings III, 10-17.

RALSTON, D. J. \& BAER, B. S. (1964a). A new property of phage group II Staphylococcus aureus strains: host restriction of phage KI4. Journal of General Microbiology 36, 1-16.

Ralston, D. J. \& BaER, B. S. (1964b). Propagation of Staphylococcus typing phages on a common host, Staphylococcus aureus $\mathrm{KI}$, and host-controlled changes in their lytic range. Journal of General Microbiology 36, $17-24$.

Ralston, D. J. \& BAER, B. S. (1964c). Host-controlled changes of staphylococcal phage $3 \mathrm{C}$ affecting its broad group typing pattern. Journal of General Microbiology 36, 25-36.

Rountree, P. M. (1959). Changes in the phage typing patterns of staphylococci following lysogenization. Journal of General Microbiology 20, 620-633.

Simmon, V. F. \& LeDerberg, S. (I972). Degradation of bacteriophage lambda deoxyribonucleic acid after restriction by Escherichia coli K12. Journal of Bacteriology Ir2, 16I-169.

StOBberingh, E. E. (1975). Restriction and modification in Staphylococcus aureus. Thesis, Utrecht University.

Sussenbach, J. S., Monfoort, C. H. \& Stobberingh, E. E. (1976). A restriction endonuclease from Staphylococcus aureus. Nucleic Acid Research 3, 3193-3202.

Verhoef, J., van Boven, C. P. A. \& Holtrigter, B. (1972). Host-controlled modification and restriction of phages in coagulase-negative staphylococci. Journal of General Microbiology 7r, 231-239.

VAN DER VIJVER, J. C. M., VAN Es-BOON, M. M. \& MiChel, M. F. (1975). Induction of mutation in Staphylococcus aureus by ethyl methanesulfonate. Journal of Medical Microbiology 2, 265-279.

WINKLER, K. C. \& GROOTSEN, C. (196I). The relation of phage pattern and lysogenicity in the phage-typing of staphylococci of phage group II. Antonie van Leeuwenhoek 27, 225-246.

Winkler, K. C., de WaArt, J., Grootsen, C., Zegers, B. J. M., Tellier, N. F. \& Vertregt, C. D. (1965). Lysogenic conversion of staphylococci to loss of $\beta$-toxin. Journal of General Microbiology 39, $321-333$.

WooD, W. B. (1966). Host specificity of DNA produced by Escherichia coli. Bacterial mutations affecting the restriction and modification of DNA. Journal of Molecular Biology 16, I $18-133$. 